Check for updates

Cite this: RSC Adv., 2018, 8, 6293

Received 3rd December 2017 Accepted 23rd January 2018

DOI: 10.1039/c7ra12997a

rsc.li/rsc-advances

\section{Enhanced biodegradation of phenol in a novel cyclic activated sludge integrated with a rotating bed bioreactor in anoxic and peroxidase-mediated conditions}

\begin{abstract}
Mojtaba Pourakbar, (D) a Gholamreza Moussavi ${ }^{\star a}$ and Kamyar Yaghmaeian ${ }^{\text {bc }}$
Cyclic activated sludge integrated with a rotating bed bioreactor (CASIR) was used for phenol biodegradation. The effects of phenol loading rate, mixed liquor suspended solids (MLSS) concentration, media filling ratio, hydraulic retention time (HRT) and salinity were investigated for phenol degradation and COD removal. In the second phase of the study, the microbial content of the bioreactor was induced by hydrogen peroxide injection for in situ generation of peroxidase. For investigating the above-mentioned parameters, the bioreactor was operated for 535 days and residual phenol, nitrate and COD were measured daily. The variation of the dehydrogenase activity and peroxidase activity of suspended biomass and attached film were also monitored during the bioreactor operation. Complete degradation of phenol at the loading rate of $667 \mathrm{~g} \mathrm{~m}^{-3} \mathrm{~d}^{-1}$ was achieved in anoxic conditions. Addition of media to the bioreactor to form active attached biofilm led to the increase in tolerance of the bioreactor on organic loading shocks. It was found that increasing the salinity of the wastewater did not affect the performance of the bioreactor. Investigating dehydrogenase activity proved that the attached biofilm was more involved in phenol degradation, compared with the suspended biomass. However, after switching to peroxidase-mediated conditions, the organic loading tolerance of the bioreactor considerably increased and complete degradation of phenol at the loading rate of $2000 \mathrm{~g} \mathrm{~m}^{-3} \mathrm{~d}^{-1}$ was reached. After adaptation of the microorganisms for hydrogen peroxide, the peroxidase activity of $290 \mathrm{U}_{\text {gbiomass }}{ }^{-1}$ was observed in the bioreactor. Accordingly, the $\mathrm{H}_{2} \mathrm{O}_{2}{ }^{-}$ induced microbial cells in cyclic activated sludge could be considered as a promising technique for enzymatic degradation of phenol and corresponding COD.
\end{abstract}

\section{Introduction}

Phenol is regarded as a toxic aromatic compound that has been placed on the priority pollutant list by the United States Environmental Protection Agency (USEPA). Phenolic compounds are commonly detected in industrial wastewaters from industries such as petrochemical, pharmaceutical, textile, and paint, and are threatening to the environment. It is reported that almost 700 million tons of phenol are produced annually. ${ }^{1}$ Excessive discharge of phenol through wastewater into aqueous ecosystems causes serious environmental pollution, even at low concentrations. $^{2}$ The EPA has regulated the concentration of phenol in wastewater below $2 \mathrm{mg} \mathrm{L}^{-1}$ in order to protect human health from the potential toxic effects caused by exposure to

${ }^{a}$ Department of Environmental Health Engineering, Faculty of Medical Sciences, Tarbiat Modares University, Tehran, Iran. E-mail: ppourakbar@yahoo.com; moussavi@modares.ac.ir; Fax: +982182883863; Tel: +982182883827

${ }^{b}$ Department of Environmental Health Engineering, School of Public Health, Tehran University of Medical Sciences, Tehran, Iran.E-mail: kyaghmaeian@tums.ac.ir

${ }^{c}$ Center for Water Quality Research, Institute for Environmental Resarch, Tehran University of Medical Sciences, Tehran, Iran phenol. ${ }^{3}$ In general, it is of vital importance to remove phenol from wastewater prior to discharge to the environment. However, phenol is not easily removed from its dissolved state in water due to its considerable molecular polarity, which brings about its high solubility over $10 \mathrm{wt} \%$. To protect human health and the ecosystem, the development of an efficient and environmentally-friendly technique to remove phenol from its aqueous solution is of great importance.

Several investigations have been carried out to remove phenol from industrial phenol-laden wastewaters, including a combination of physical, chemical and biological processes. Conventional physicochemical technologies for phenol removal include oxidation, ion-exchange, adsorption, electrocoagulation, etc. ${ }^{4-6}$ On the other hand, biological processes have been preferred to physical and chemical technologies due to their ability to destroy a wide range of pollutants in an environmentally friendly and cost effective way. ${ }^{7-9}$ Several studies have been conducted regarding the biodegradation of phenol from wastewater. ${ }^{\mathbf{1 0 - 1 3}}$ Although phenol degradation can occur in both aerobic and anaerobic conditions, studies have shown that phenol degradation in aerobic conditions is better than in 
anaerobic conditions because phenol can inhibit the anaerobic biological processes. ${ }^{\mathbf{1 4}}$ However, due to the need for aeration of the wastewater, aerobic processes have high energy consumption. On the other hand, phenolic compounds can be found together with other pollutants such as nitrates in wastewater. The use of nitrate as the final electron acceptor in the oxidation of phenol, as the carbon source of microorganisms, makes the biological process more interesting. ${ }^{15}$ Therefore, anoxic degradation of phenol from wastewater leads to the removal of both phenol and nitrate, and the problems associated with the aeration of the wastewater are eliminated.

Microorganisms, either aerobic or anoxic, in phenol biological oxidation can be attached to a medium or suspended in the bioreactor. Several studies have been conducted using suspended and attached growth microorganisms for phenol degradation..$^{13,16-18}$ It has been reported that attached biofilm is more resistant to toxic compounds compared to suspended biomass; for example, Tziotzios et al. ${ }^{19}$ reported that a packed bed reactor led to higher phenol degradation, as compared with a suspended growth bioreactor, especially when the packed bed reactor is operated in fill and draw mode. Yusoff et al. ${ }^{20}$ reported in 2016 that in hybrid growth systems (including suspended and attached growth systems) the inhibitory effect of phenol towards the biochemical activities of the microorganisms was minimized.

Cyclic operation is a modification of the conventional activated sludge process, which is conducted in a variable volume reactor. The process operates with sludge in a single reactor basin to accomplish both biological treatment and solid-liquid separation. The sequencing batch reactor (SBR) is the commonly used cyclic activated sludge process. The sequencing continuous reactor (SCR) was subsequently developed as the modification of the SBR. Considering the advantages of attached biofilm, such as larger microbial diversity and biochemical activities, having large biomass contained per volume of bioreactor, higher degradation rate, higher resistance to toxic shocks and prevention of biomass washout, ${ }^{21}$ a hybrid suspended biomass and attached biofilm bioreactor were developed to degrade phenol from wastewater. Cyclic Activated Sludge Integrated with a Rotating bed (CASIR) is a newly developed and modified bioreactor of SCR having both attached growth and suspended growth.

In recent years, enzymatic biodegradation of recalcitrant compounds have been conducted by several researchers. Enzymatic biodegradation is considered as a promising approach for pollutant biodegradation due to substrate specificity, efficiency and the ease of handling. ${ }^{22}$ In enzymatic biodegradation, microorganisms generate intracellular and extracellular enzymes. ${ }^{23}$ The presence of peroxidase enzyme, an oxidoreductase enzyme, in the wastewater could lead to the generation of free radicals initiating bond-cleavage reactions and subsequent degradation of the organic compounds would occur. ${ }^{23}$ Bacterial biostimulation for the generation of peroxidase enzyme has been reported to be effective for pollutant degradation. Bacterial biostimulation by hydrogen peroxide causes peroxidase generation to protect the living cells. ${ }^{24}$ Therefore, addition of $\mathrm{H}_{2} \mathrm{O}_{2}$ to the bioreactors is an interesting choice for in situ generation of peroxidase.
Accordingly, the present study is aimed toward investigating the performance of the CASIR bioreactor for phenol degradation in anoxic conditions and compares the performance with peroxidase-mediated conditions. The effect of inlet phenol concentration, Mixed Liquor Suspended Solids (MLSS), media filling ratio, Hydraulic Retention Time (HRT), and salinity were evaluated on phenol and COD removal.

\section{Experimental}

\subsection{Synthetic wastewater}

The synthetic wastewater was generated by dissolving a known amount of phenol as the sole carbon source in dechlorinated tap water. The required nutrients for microbial metabolism were added into the synthetic wastewater to maintain the COD/ $\mathrm{N} / \mathrm{P}$ ratio of $100 / 5 / 1$. The stock nutrient solution consisted of $15 \mathrm{~g} \mathrm{KH}_{2} \mathrm{PO}_{4}, 5 \mathrm{~g} \mathrm{~K}_{2} \mathrm{HPO}_{4}, 120 \mathrm{~g} \mathrm{NH} \mathrm{NH}_{4} \mathrm{Cl}, 10 \mathrm{~g} \mathrm{CaCO}_{3}, 12 \mathrm{~g}$ $\left(\mathrm{NH}_{4}\right)_{2} \mathrm{HPO}_{4}$, and $10 \mathrm{~g} \mathrm{NaHCO}_{3}$ in one liter of tap water. The $\mathrm{pH}$ of the synthetic wastewater was maintained at neutral conditions. All the chemicals used in the present study were of analytical grade and were purchased from Merck.

\subsection{Experimental setup}

The experiments were carried out in a cylindrical glass with a diameter of $20 \mathrm{~cm}$ and height of $36 \mathrm{~cm}$ (25 cm fixed height). Fig. 1 illustrates the schematic of the CASIR bioreactor. The feed into the bioreactor was conducted by a peristaltic pump (WATSON MARLOW 101U/R). A perforated basket was used to hold polyurethane foam (PUF) cubes $\left(1 \mathrm{~cm}^{3}\right)$ with density of $35 \mathrm{~kg} \mathrm{~m}^{-3}$ and specific surface area of $600 \mathrm{~m}^{2} \mathrm{~m}^{-3}$. The media package was rotated inside the bioreactor with an electromotor $(14 \mathrm{~W})$, which was connected by a steel shaft. Supernatant decantation was conducted using a solenoid valve controlled by a timer. Another timer was also connected to the electromotor to control the reaction and settling times in the bioreactor. The bioreactor was operated in cyclic mode and each cycle lasted for $3 \mathrm{~h}$, consisting of reaction $(2 \mathrm{~h})$, settling $(0.75 \mathrm{~h})$, and decanting $(0.25 \mathrm{~h})$. Injection of synthetic wastewater was carried out continuously from the bottom of the bioreactor.

\subsection{Inoculum, start-up and operation}

The bioreactor was filled with activated sludge used for catechol degradation in our previous study. ${ }^{25}$ The CASIR bioreactor contained a mixed microbial culture with both attached growth and suspended growth. The concentration of MLSS was regulated at $4000 \pm 200 \mathrm{mg} \mathrm{L}^{-1}$. Both the suspended biomass and attached thin active biofilm were responsible for phenol degradation in the CASIR bioreactor. Suspension of the biomass in the reaction step was obtained by rotation of the media package. To determine the amount of attached biofilm, 5 pieces of media were withdrawn from the middle of the basket and the attached biofilm was washed with $200 \mathrm{~mL}$ of nutrient solution to detach the biofilm. The concentration of the nutrient solution containing the detached biofilm was measured and the amount of biofilm attached to each media was calculated to be 
$58.08 \mathrm{mg}$. Considering the total of 125 pieces of media in the bioreactor, the total attached biofilm was calculated to be $7.2 \mathrm{~g}$. Further measurement of the biofilm during different operational times revealed that there was not a considerable difference in the amount of attached biofilm.

In the present study, nitrate was used as the final electron acceptor, and the inlet nitrate concentration was determined based on the inlet COD concentration and the COD/nitrate ratio was selected to be $1 .^{25,26}$ Initially, the reactor was operated with $100 \mathrm{mg} \mathrm{L}^{-1}$ phenol. The start-up phase was assumed to be complete after reaching $100 \%$ phenol removal. After the start-up period, the effects of inlet phenol concentration (100-800 $\left.\mathrm{mg} \mathrm{L}^{-1}\right)$, MLSS (4-7 $\left.\mathrm{g} \mathrm{L}^{-1}\right)$, media filling ratio $(0-40 \%)$, HRT $(12-24 \mathrm{~h})$, and salinity $\left(1-20 \mathrm{~g} \mathrm{~L}^{-1}\right)$ were investigated.

In the second phase of the study, the bioreactor was switched from reducing conditions (anoxic) to oxidizing conditions in which hydrogen peroxide acted as the final electron acceptor. To get these conditions, the nitrate concentration in the effluent wastewater was reduced gradually and hydrogen peroxide was added using a syringe pump (Fig. 1).

Table 1 summarizes the experimental phases. Media filling ratio is defined as the volume of the media to total working volume of the bioreactor. Each experimental condition was set up to reach pseudo-steady state conditions in terms of effluent COD. Pseudo-steady state conditions were assumed to be reached when the effluent COD fluctuation was less than $3 \%$ in at least 3 consecutive days of operation (3HRT). All the experiments were conducted at room temperature $\left(20 \pm 2{ }^{\circ} \mathrm{C}\right)$.

\subsection{Analytical methods}

The samples were collected daily and were analyzed for residual phenol concentration, COD, nitrate and nitrite. The MLSS of the bioreactor was also monitored on a routine basis. The dehydrogenase activities (DHA) of both suspended biomass and attached biofilm were also routinely monitored. The decanted supernatant was filtered to remove particles with a $0.45 \mu \mathrm{m}$ pore size filter prior to measuring phenol, COD, nitrate and nitrite concentrations. The phenol concentration was measured spectrophotometrically using the colorimetric 4-aminoantipyrine procedure as given in the standard methods ${ }^{27}$ using a Unico-UV $2100 \mathrm{UV} /$ vis spectrophotometer. $\mathrm{pH}$ was measured using a Jenway $3505 \mathrm{pH}$ meter. All the other parameters including COD, nitrate, nitrite, and the MLSS were measured according to the procedures given in standard methods. ${ }^{27}$

The performance of the CASIR bioreactor was measured based on the COD and phenol removal efficiencies as a function of inlet phenol and COD concentrations (eqn (1)). In addition, the phenol loading rate was calculated using the following equations:

$$
\text { Removal efficiency }(\%)=\frac{\left(C_{0}-C_{\mathrm{t}}\right)}{C_{0}} \times 100
$$

Phenol loading rate $\left(\mathrm{g}\right.$ phenol per $\mathrm{m}^{3}$ per day) $=\frac{\text { phenol }_{\text {in }}}{\text { HRT }}$

where, $C_{0}$ and $C_{\mathrm{t}}$ are the phenol and COD concentrations in the inlet and outlet of the bioreactor, respectively.

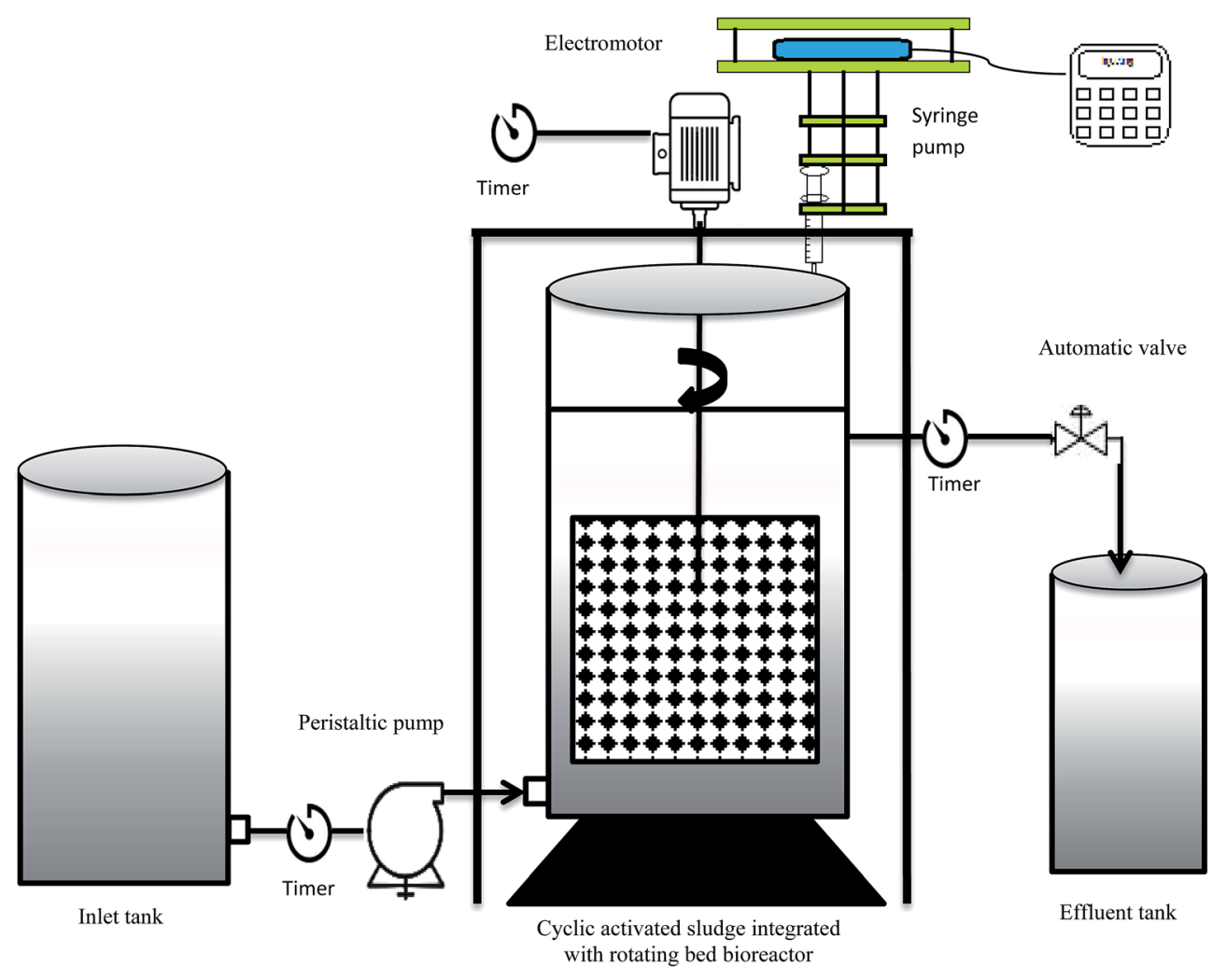

Fig. 1 Schematic of the cyclic activated sludge integrated with rotating bed bioreactor. 
Table 1 Experimental and operation conditions

\begin{tabular}{llllll}
\hline $\begin{array}{l}\text { Salinity } \\
\left(\mathrm{g} \mathrm{L}^{-1}\right)\end{array}$ & $\begin{array}{l}\text { Media filling } \\
\text { ratio (\%) }\end{array}$ & $\begin{array}{l}\text { HRT } \\
(\mathrm{h})\end{array}$ & $\begin{array}{l}\text { MLSS } \\
\left(\mathrm{g} \mathrm{L}^{-1}\right)\end{array}$ & $\begin{array}{l}\text { Inlet phenol concentration } \\
\left(\mathrm{mg} \mathrm{L}^{-1}\right)\end{array}$ & Operation condition \\
\hline Tap water & 40 & 24 & 4 & 100 & Start-up \\
Tap water & 40 & 24 & 4 & $100-800$ & Inlet phenol concentration \\
Tap water & 40 & 24 & $4-7$ & 800 & MLSS \\
Tap water & $0-40$ & 24 & 4 & 500 & Media filling ratio \\
Tap water & 40 & $12-24$ & 4 & 500 & HRT \\
$0-20$ & 40 & 24 & 4 & 800 & Salinity \\
Tap water & 40 & 12 & 4 & 500 & $\mathrm{H}_{2} \mathrm{O}_{2}$ injection \\
\end{tabular}

The dehydrogenase enzyme activity (DHA) of the suspended biomass and attached growth was measured at the end of each experimental run when the reactor was in steady-state conditions.

Triphenyl tetrazolium chloride (TTC) was used as the hydrogen acceptor for the dehydrogenase test. ${ }^{28}$ TTC in the presence of dehydrogenase enzymes produces a red color, which is due to the generation of 1,3,5-triphenyltetrazolium formazan (TF). This red color could be measured spectrophotometrically at $492 \mathrm{~nm}$. The generated TF is water insoluble and it was extracted using toluene. ${ }^{29} \mathrm{TF}$ was used to establish a standard curve for absorbance $v s$. TF concentration. Tris- $\mathrm{HCl}$ $(\mathrm{pH}=7.6)$ was also used to control the $\mathrm{pH}$ of the samples. Mixed liquor samples taken from the bioreactor were added to tubes containing $2 \mathrm{~mL}$ of tris- $\mathrm{HCl}$ buffer, $2 \mathrm{~mL}$ of glucose solution $(0.1 \mathrm{M})$, and $2 \mathrm{~mL}$ of TTC $(5 \%)$. The tubes were then incubated in a water bath at $37{ }^{\circ} \mathrm{C}$ and incubated for $24 \mathrm{~h}$. After the incubation period, the reaction was stopped by adding $2 \mathrm{~mL}$ of sodium dithionate $\left(\mathrm{Na}_{2} \mathrm{~S}_{2} \mathrm{O}_{4}\right)$. Then, $5 \mathrm{~mL}$ of toluene was added to the tubes and the contents of the tubes were centrifuged at $5000 \mathrm{rpm}$ for $10 \mathrm{~min}$ afterward, the supernatant was used for TF measurement. Finally, DHA was expressed in terms of $\mu \mathrm{g}$ TF per $\mathrm{g}_{\text {biomass }}$ per day.

Peroxidase activity (PA) was measured based on the procedure given by Tandjaoui et al.,${ }^{30}$ with some modifications. Based on this method, $10 \mathrm{~mL}$ of the mixed liquor was taken and centrifuged at $10000 \mathrm{rpm}$ at $4{ }^{\circ} \mathrm{C}$ for $20 \mathrm{~min}$. Afterward, $40 \mu \mathrm{L}$ of the supernatant was taken and $350 \mu \mathrm{L}$ buffer phosphate $(0.3 \mathrm{M}$, $\mathrm{pH}=7), 100 \mu \mathrm{L}$ guaiacol and $160 \mu \mathrm{L} \mathrm{H}_{2} \mathrm{O}_{2}$ solutions were added in a UV-Vis spectrophotometer. Then, the changes in the absorbance at $470 \mathrm{~nm}$ were monitored for $5 \mathrm{~min}$. The PA was expressed as $\mathrm{U} \mathrm{g}_{\text {biomass }}{ }^{-1}$ indicating the amount of peroxidase produced per unit of biomass, which oxidized $1 \mu \mathrm{mol}$ of substrate per min at $25{ }^{\circ} \mathrm{C} .{ }^{30}$

\section{Results and discussion}

\subsection{Bioreactor start-up and the effect of inlet phenol concentration}

The performance of the bioreactor was investigated for inlet phenol concentrations of $100-800 \mathrm{mg} \mathrm{L}^{-1}$, corresponding to COD concentrations of $230-1900\left(\mathrm{mg} \mathrm{L}^{-1}\right)$ at an HRT value of 24 h. Fig. 2a shows the phenol and corresponding COD removal efficiencies within 120 days of operation. The bioreactor was started up by injecting with inlet phenol concentration of $100 \mathrm{mg} \mathrm{L}^{-1}$. As shown, the removal efficiency of phenol after 15 days of operation reached $90 \%$, and continuing the operation of the bioreactor led to the complete removal of phenol after 20 days. In addition, COD removal efficiency of almost $94 \%$ was reached after this period of operation. Furthermore, nitrate was also reduced and almost $98 \%$ of nitrate removal efficiency was reached. After reaching steady-state conditions within this time, the concentration of inlet phenol increased to $200 \mathrm{mg} \mathrm{L}^{-1}$. As shown in Fig. 2a, there was a small reduction in the removal efficiency in the first few days, but this was very short-lived and the efficiency improved to complete removal after 5 days of operation, showing the completion of the start-up phase. The rapid time of start-up could be due to inoculating the bioreactor with adapted phenolic compound degrader biomass. After the start-up section, the bioreactor was operated at inlet phenol concentrations of 400,600 , and $800 \mathrm{mg} \mathrm{L}^{-1}$. Initial phenol concentration is of great importance in the performance of the continuous biodegradation process, since some hydrocarbon contaminants such as phenol are known to have inhibitory effects on the activity of the biomass. At the inlet phenol concentration of $600 \mathrm{mg} \mathrm{L}^{-1}$, complete degradation of phenol along with $93 \%$ COD removal was reached, but increasing the inlet phenol concentration to $800 \mathrm{mg} \mathrm{L}^{-1}$ with a corresponding inlet COD concentration of $1900 \mathrm{mg} \mathrm{L}^{-1}$ led to decreased phenol and COD removal efficiency below $90 \%$ and $74 \%$, respectively, after 15 days of operation. This implies that the critical phenol concentration for the anoxic bioreactor was $800 \mathrm{mg} \mathrm{L}^{-1}$ at HRT value of $24 \mathrm{~h}\left(800 \mathrm{~g} \mathrm{~m}^{-3} \mathrm{~d}^{-1}\right)$. Concentrations larger than this have an inhibitory effect on the activity of the biomass and may lead to the accumulation of intermediates in the bioreactor. ${ }^{31}$ Nitrites in the effluent were also measured during this phase, and no nitrite accumulation was observed at

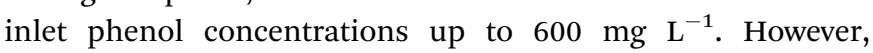
increasing the inlet phenol concentration to $800 \mathrm{mg} \mathrm{L}^{-1}$ led to the appearance of $0.8 \mathrm{mg} \mathrm{L}^{-1}$ nitrite in the effluent.

As shown in Fig. 2a, the COD removal shows the same trend as phenol removal, implying that phenol is metabolized for energy production via active biomass and has been completely biodegraded.

Sarfaraz et $a .^{32}$ reported that complete degradation of $649 \mathrm{mg} \mathrm{L}^{-1}$ phenol was reached in an anoxic granular SBR with $12 \mathrm{~h}$ cycle length. Bajaj et al. $^{33}$ investigated the performance of an anoxic suspension bioreactor for phenol degradation and 

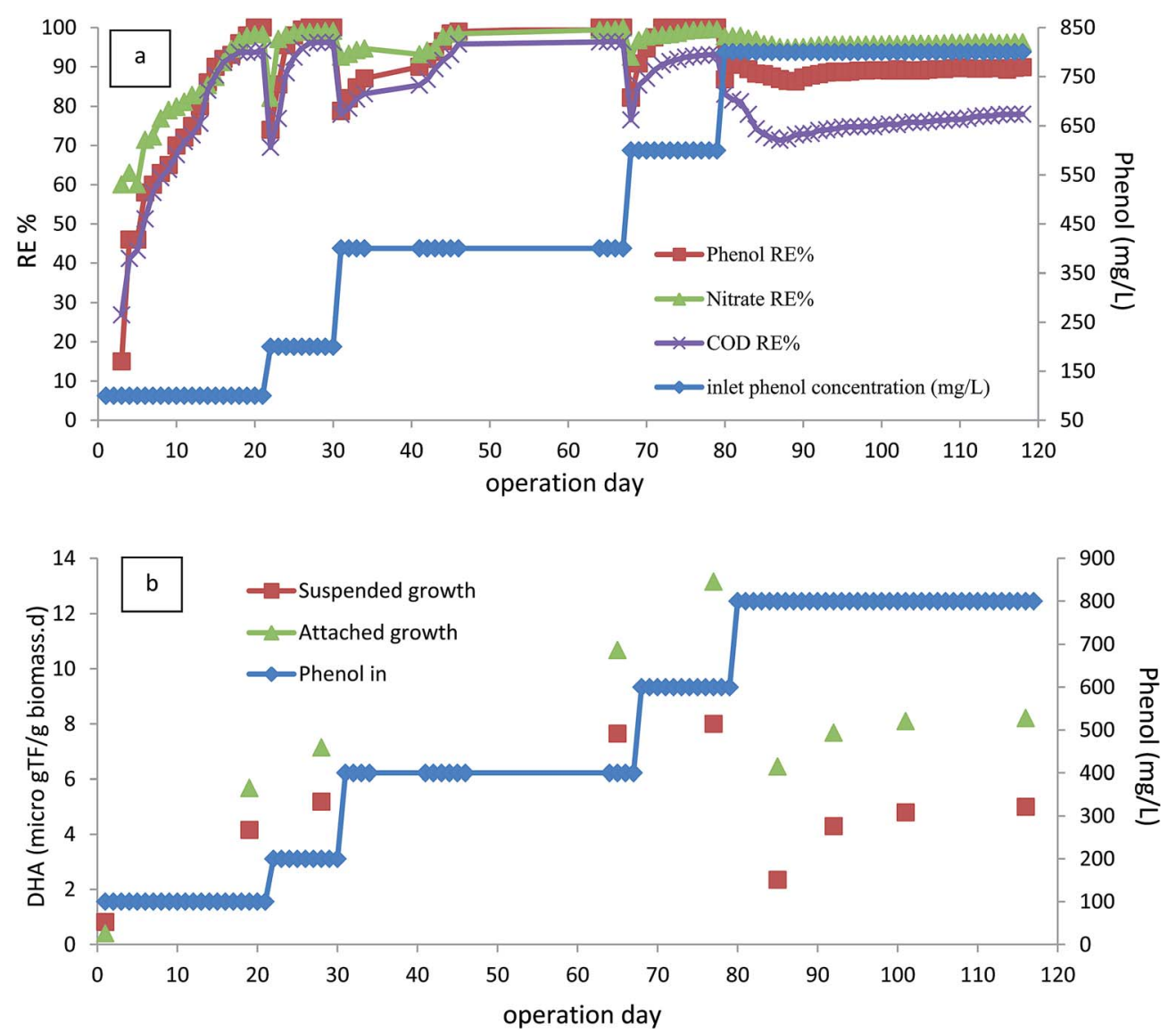

Fig. 2 (a) Start-up and the effect of inlet phenol concentration on phenol, COD and nitrate removal. (b) Variation of DHA within the start-up stage and varying inlet phenol concentration. (HRT $=24 \mathrm{~h}$, media filling ratio $=40 \%, \mathrm{MLSS}=4000 \mathrm{mg} \mathrm{L}^{-1}$ ).

found that $207 \mathrm{mg} \mathrm{L}^{-1}$ phenol was almost completely degraded; when the inlet phenol concentration increased to $329 \mathrm{mg} \mathrm{L}^{-1}$ there was significant reduction in both phenol and COD removal. Rosenkranz et al..$^{34}$ investigated an anaerobic SBR for degradation of phenol in synthetic wastewater; they reported that $800 \mathrm{mg} \mathrm{L}^{-1}$ of phenol was almost completely degraded at reaction time of $50 \mathrm{~h}$. Liu et al. ${ }^{13}$ reported that $300 \mathrm{mg} \mathrm{L}^{-1}$ phenol was $99 \%$ biodegraded in an anoxic-aerobic bioreactor; most of the phenol was degraded in the anoxic stage. As seen in the literature, the performance of the anoxic CASIR is better compared to other similar anoxic bioreactors. This could be due the use of an acclimated culture of active microorganisms in the bioreactor and the presence of active attached biofilm, which had a considerable effect on the overall performance of the bioreactor. To prove this fact, DHA of the suspended biomass and attached biofilm was measured at different operational runs with varying inlet phenol and COD concentrations. Fig. $2 \mathrm{~b}$ illustrates the DHA of the CASIR process within 118 days of operation. The lowest DHA in the bioreactor was at the start-up stage; after completion of the start-up stage and increasing the inlet phenol concentration, the DHA of suspended biomass was also increased from $0.82 \mu \mathrm{g}$ TF per g $\mathrm{g}_{\text {biomass }}$ per day in the first day of operation to $8 \mu \mathrm{g}$ TF per $g_{\text {biomass }}$ per day on day 79 (inlet phenol concentration of $600 \mathrm{mg} \mathrm{L}^{-1}$ ). The same trend was observed for attached biofilm, but the DHA values at the first day and $79^{\text {th }}$ day were 0.41 and $13.15 \mu \mathrm{g}$ TF per g biomass $_{\text {ber }}$ day, respectively. This increase in DHA shows that the microorganisms consume the substrate for their metabolic activities. This may be due the fact that the phenol concentration up to the given point can stimulate the DHA and cause enhanced bacterial growth and biodegradation rate..$^{35,36}$ When the inlet phenol concentration increased to the critical point of $800 \mathrm{mg} \mathrm{L}^{-1}$, there was a significant reduction in DHA, indicating that the bioreactor is operating at the tolerance threshold. The reduction in phenol and COD removal efficiencies at the higher loading rates implies that the microorganisms are acting at their maximum capacity in the metabolic activities. ${ }^{37}$ In our previous study, the SCR bioreactor was used for petroleum hydrocarbon degradation, DHA activity was also reduced at critical inlet concentration. ${ }^{38}$

\subsection{The effect of the concentration of mixed liquor suspended solids}

The effect of MLSS concentrations of $4-7 \mathrm{~g} \mathrm{~L}^{-1}$ was investigated in the following conditions: inlet phenol concentration $=$ $800 \mathrm{mg} \mathrm{L}^{-1}, \mathrm{HRT}=24 \mathrm{~h}$, and media filling ratio $=40 \%$. When the MLSS of the bioreactor was increased to $5 \mathrm{~g} \mathrm{~L}^{-1}$, there was a slight increase in the removal efficiencies of phenol, COD, and nitrate. Increasing the MLSS concentration up to $7 \mathrm{~g} \mathrm{~L}^{-1}$ leads 
to the increase in phenol removal efficiency. As shown in Fig. 3a, $800 \mathrm{mg} \mathrm{L}^{-1}$ phenol was completely biodegraded and $92 \%$ COD removal was reached at this stage. The reason for higher phenol and COD removal at higher MLSS is due to the higher number of active microorganisms present in the bioreactor. ${ }^{39}$ By increasing the concentration of microorganisms in the bioreactor, the ratio of inlet food to microorganisms became smaller, causing an increment in the COD and phenol removal efficiencies. ${ }^{40}$ Although there were higher removal efficiencies for phenol and COD at higher concentrations of suspended biomass, bioreactor operation at higher levels of suspended biomass was difficult, and clogging of the outlet due to the sludge rising was a common problem.

Fig. 3b illustrates the performance of the CASIR bioreactor with DHA as a function of MLSS concentration. As shown in the figure, there was a slight increase in DHA of the suspended biomass and attached biofilm. This is due to the fact that further degradation of phenol and its intermediates reduces the toxicity of phenol to the microorganisms and therefore stimulates DHA. In addition, the increase in the DHA activity of the attached biofilm is greater than that of the suspended biomass. This is due to the fact that when calculating the DHA of the suspended biomass, the value of $\mathrm{mg}_{\text {biomass }}$ in the denominator increases and therefore the overall DHA is reduced. On the other hand, DHA of the biofilm increases, which is due to the reduction in the phenol concentration present in the reactor. Immobilized biomass on an inert surface allows more active working organisms in the bioreactor with more stable operation; this is achieved by improving the retention of microorganisms, allowing the reactor to cope with a greater concentration of biomass. Therefore, the integration of attached growth with suspended growth in the CASIR bioreactor makes the process more stable and effective in phenol degradation.

\subsection{The effect of media filling ratio}

In order to investigate the effect of the presence of attached biofilm on the performance of the bioreactor, all the media were taken out and the inlet phenol concentration was reduced to $100 \mathrm{mg} \mathrm{L}^{-1}$. Fig. 4a illustrates the performance of the bioreactor without any attached biofilm growth at inlet phenol concentrations of $100-500 \mathrm{mg} \mathrm{L}^{-1}$. As shown in the figure, the process could completely degrade inlet phenol concentration of $400 \mathrm{mg} \mathrm{L}^{-1}$, and almost $87 \%$ COD removal was achieved, but further increase of inlet phenol concentration to $500 \mathrm{mg} \mathrm{L}^{-1}$ led to the reduction of phenol to $73.8 \%$ and COD removal to $69.74 \%$. DHA was also decreased from 6.8 to $3.01 \mu \mathrm{g}$ TF per $\mathrm{g}_{\text {biomass }}$ per day (Fig. 4b).
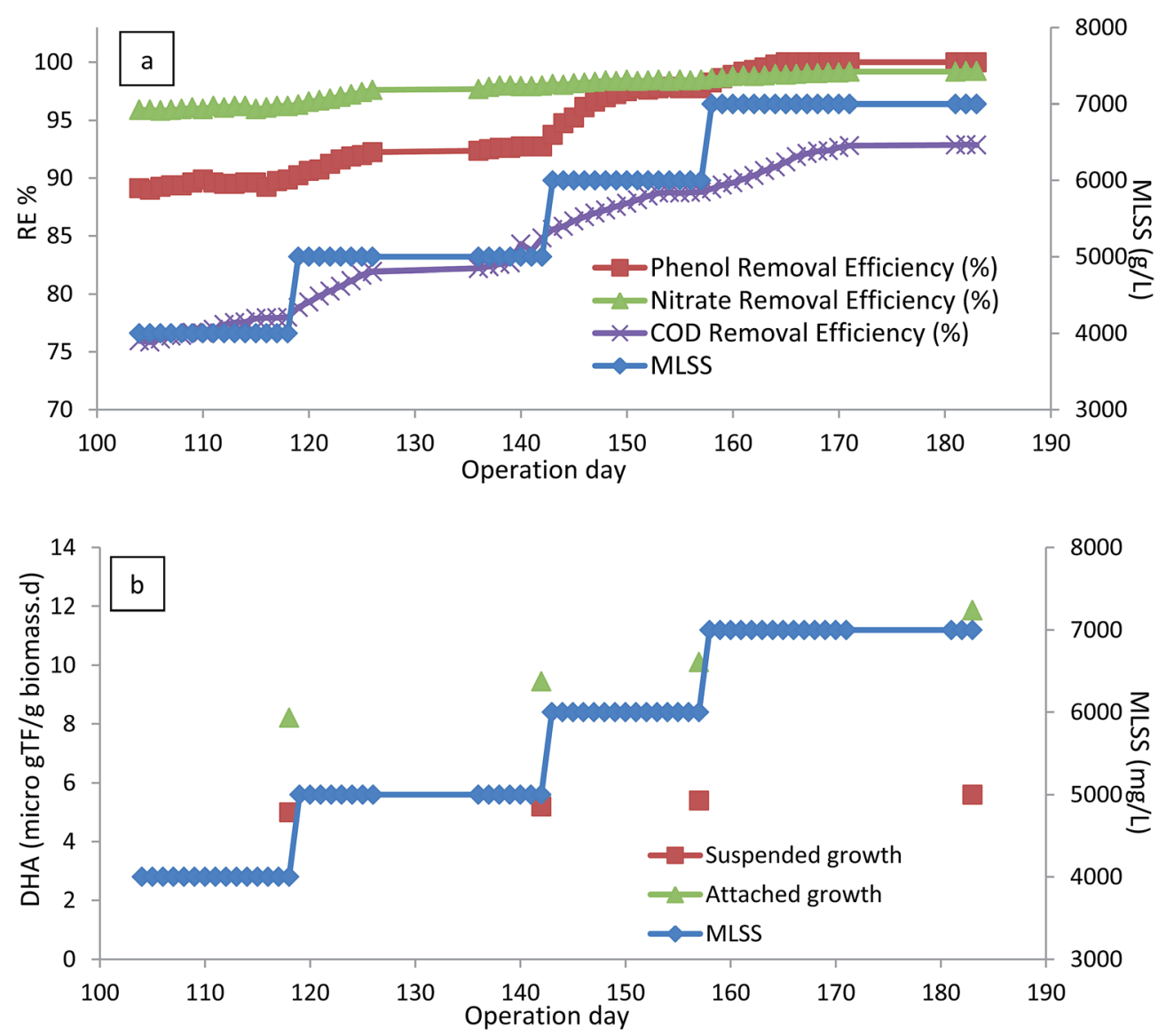

Fig. 3 (a) Effect of MLSS on the performance of the bioreactor. (b) Variation of DHA as a function of MLSS. (HRT $=24 \mathrm{~h}, \mathrm{media}$ filling ratio $=40 \%$, inlet phenol concentration $=800 \mathrm{mg} \mathrm{L}^{-1}$ ). 
In the next section, in order to see the effect of the presence of biofilm in the bioreactor, the media filling ratio increased to $10 \%$. The presence of media with attached growth biofilm, increased the removal efficiency of phenol to $95.8 \%$ after 15 days of operation, and COD removal increased to $88.06 \%$. Further increase of the media filling ratio to $20 \%$ led to $100 \%$ removal of phenol and $91 \%$ of COD was also removed. After reaching steady-state conditions, the media filling ratio increased to 30 and $40 \%$ and finally $94.28 \%$ of COD was removed. It can be seen that phenol, nitrate and COD removal efficiencies were increasing just after inserting the media, and steady-state conditions were quickly reached after increasing the media filling ratio.

Fig. 5 illustrates the average steady-state phenol, COD, and nitrate removals at varying media filling ratios. As shown in the figure, $100 \%$ removal of $500 \mathrm{mg} \mathrm{L}^{-1}$ phenol was reached by $30 \%$ media filling ratio. More mineralization of organic compounds in the bioreactor occurred by further increasing the media filling ratio. Biofilm generation in the bioreactor caused the increment in DHA, as seen in Fig. 5, due to the presence of more active working microorganisms, which caused a reduction in the toxicity of the phenol. ${ }^{16}$
Integration of suspended biomass with attached biofilm in the CASIR bioreactor also led to improvement of the quality of the effluent in the case of Total Suspended Solid (TSS). TSS of the effluent when there was no media in the bioreactor was measured to be $46 \mathrm{mg} \mathrm{L}^{-1}$ (HRT $=24 \mathrm{~h}$, media filling ratio = $0 \%$, inlet phenol concentration $=500 \mathrm{mg} \mathrm{L}^{-1}$, and MLSS $=$ $4000 \mathrm{mg} \mathrm{L}^{-1}$ ), but addition of the media and formation of the biofilm improved the performance of the bioreactor and the effluent TSS was reduced to $6.5 \mathrm{mg} \mathrm{L}^{-1}$. This is in accordance with the findings of other researchers. ${ }^{17}$ Highly efficient removal of TSS indicates that the integration of biofilm and suspended biomass was highly effective as an adsorbent, filtration unit and biofilm attachment mechanism such that the system was able to accept a higher organic load in the influent.

\subsection{The effect hydraulic retention time}

Providing sufficient contact time between microorganisms and contaminants is one of the important parameters in biological wastewater treatment. Therefore, the effects of HRT values of $24 \mathrm{~h}$ (corresponding to the organic loading rate of $500 \mathrm{~g} \mathrm{~m}^{-3}$ $\mathrm{d}^{-1}$ ), $18 \mathrm{~h}$ (corresponding to the organic loading rate of $667 \mathrm{~g} \mathrm{~m}^{-3} \mathrm{~d}^{-1}$ ), and $12 \mathrm{~h}$ (corresponding to the organic loading
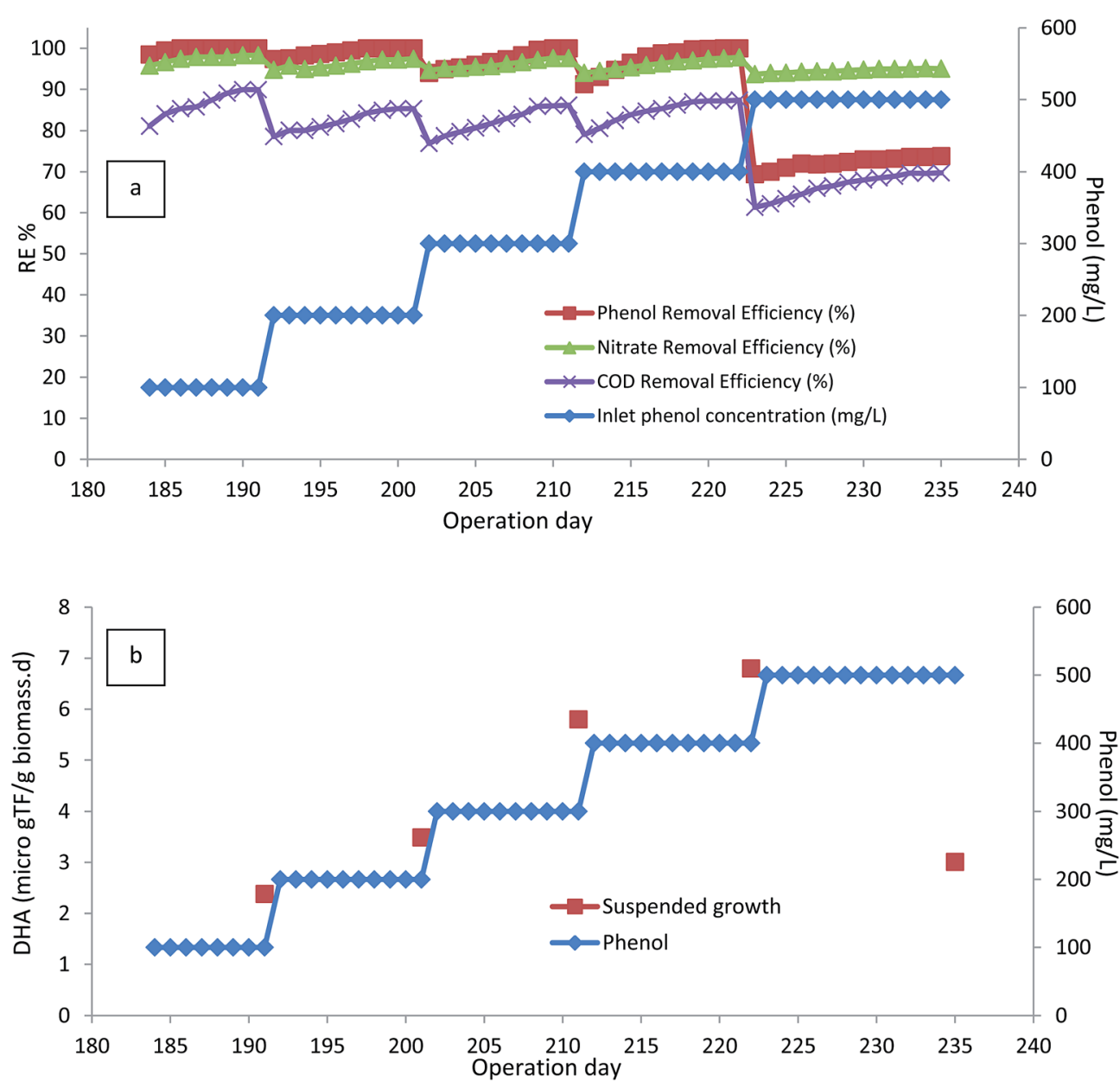

Fig. 4 (a) Performance of the bioreactor without the presence of media. (b) DHA of the bioreactor without the presence of media. (HRT $=24 \mathrm{~h}$, media filling ratio $=0 \%, \mathrm{MLSS}=4000 \mathrm{mg} \mathrm{L}^{-1}$ ). 


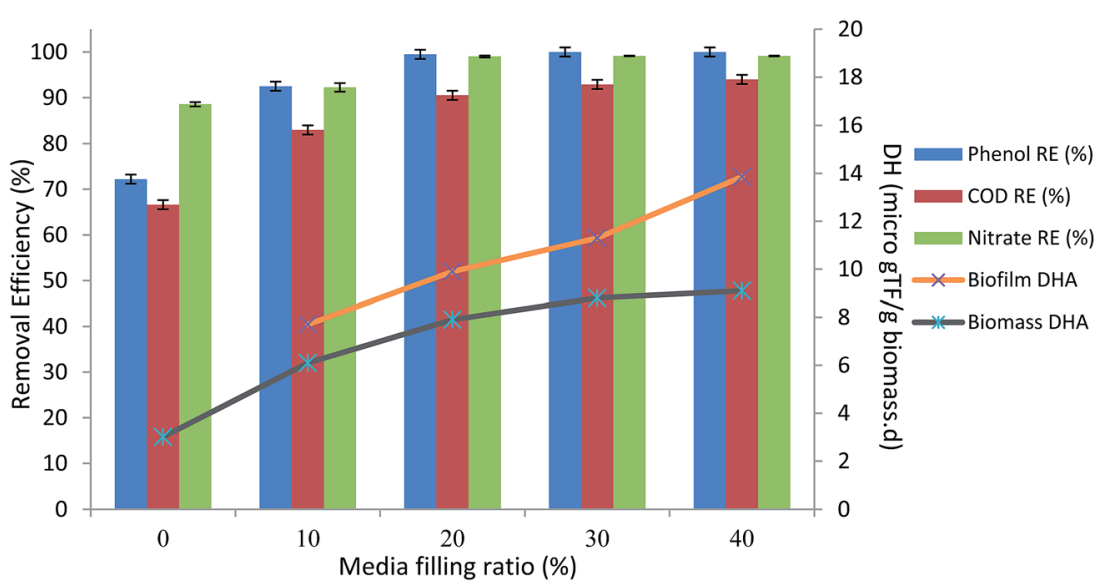

Fig. 5 Average steady-state phenol, COD, nitrate reduction and DHA variation in various media filling ratios. (HRT $=24 \mathrm{~h}$, inlet phenol concentration $=500 \mathrm{mg} \mathrm{L}^{-1}, \mathrm{MLSS}=4000 \mathrm{mg} \mathrm{L}^{-1}$ ).

rate of $1000 \mathrm{~g} \mathrm{~m}^{-3} \mathrm{~d}^{-1}$ ) on the performance of the CASIR bioreactor were investigated. This parameter was investigated at inlet phenol concentration of $500 \mathrm{mg} \mathrm{L}^{-1}$, media filling ratio of $40 \%$, and MLSS of $4000 \mathrm{mg} \mathrm{L}^{-1}$. To better understand the effect of HRT, the average steady-state phenol, COD and nitrate removal efficiencies along with corresponding DHA are presented in Table 2, which shows that reducing the HRT to $18 \mathrm{~h}$, does not affect the removal efficiency of phenol, but there is a slight reduction in COD and nitrate removal efficiencies. DHA of the biomass and biofilm also increased in the bioreactor; however, further decrease in HRT contributed to the reduction of phenol, COD and nitrate removal efficiencies. Marañón et al. ${ }^{41}$ investigated the treatment of coke wastewater containing phenol in a SBR system and observed a removal efficiency of $99 \%$ for a phenol concentration of $207 \mathrm{mg} \mathrm{L}^{-1}$ and an HRT of $115 \mathrm{~h}$, corresponding to a phenol loading rate of around $1.67 \mathrm{~g} \mathrm{~m}^{-3} \mathrm{~d}^{-1}$; for greater concentrations, they found that phenol significantly inhibited COD removal. There are also some studies reporting higher phenol loading rates, for instance, Uygur and Kargi ${ }^{42}$ reported more than 95\% COD removal in a four-step SBR (anaerobic/oxic/anoxic/oxic) at phenol concentrations up to $400 \mathrm{mg} \mathrm{L}^{-1}$ (loading rate of $1600 \mathrm{~g} \mathrm{~m}^{-3} \mathrm{~d}^{-1}$ ). Moussavi et al..$^{43}$ investigated the aerobic moving-bed sequencing batch reactor for phenol degradation; it was reported that almost $94 \%$ of phenol was degraded at the loading rate of $83.4 \mathrm{~g} \mathrm{~m}^{-3} \mathrm{~h}^{-1}$. However, the anoxic degradation of phenol with high organic loading rate is rare. Therefore, the CASIR bioreactor could be considered a promising process for the simultaneous removal of phenol and high concentrations of nitrate.

\subsection{The effect of salinity}

Salts are important raw materials in the chemical industries, various manufacturing processes and other industrial operations. Consequently, the presence of salts in industrial wastewater is inevitable. ${ }^{44}$ The occurrence of phenolic compounds in saline wastewater may limit the microbial degradation of phenol and make conventional biodegradation processes ineffective due to the adverse effect of salts on microbial metabolism; ${ }^{16,45}$ therefore, the effect of the presence of salinity $\left(1-20 \mathrm{~g} \mathrm{~L}^{-1}\right)$ on the performance of the CASIR bioreactor was investigated. To investigate the effect of salinity, the HRT of the bioreactor was increased to $24 \mathrm{~h}$, with inlet phenol concentration of $500 \mathrm{mg} \mathrm{L}^{-1}$ (organic loading rate of $500 \mathrm{~g} \mathrm{~m}^{-3} \mathrm{~d}^{-1}$ ) and the operation continued until steadystate conditions were reached. As seen in Fig. 6a, the bioreactor could recover and re-attain performance after having an organic shock load of $1000 \mathrm{~g} \mathrm{~m}^{-3} \mathrm{~d}^{-1}$ (HRT of $12 \mathrm{~h}$ ). The bioreactor could preserve its performance after the organic load was applied, revealing the high capacity of the developed reactor to amortize the shock load received. Quick recovery of the bioreactor from the organic shock load can be related to the presence of a high-density, active microbial population in the reactor, and the use of media that improves mass transfer and thus biodegradation. In addition, another reason for the observed stability of the CASIR bioreactor under organic shock loads was the batch mode of effuent decantation as well as high concentration of attached biomass, which is able to tolerate higher organic loads. ${ }^{46,47}$

Table 2 Average steady-state phenol, COD and nitrate removal efficiencies as a function of HRT (inlet phenol concentration $=500$ mg $\mathrm{L}^{-1}$, $\mathrm{MLSS}=4000 \mathrm{mg} \mathrm{L}^{-1}$ )

\begin{tabular}{|c|c|c|c|c|c|c|}
\hline $\begin{array}{l}\text { Attached biofilm DHA } \\
\text { ( } \mu \mathrm{g} \text { TF per g } \text { biomass per day) }^{\text {G }}\end{array}$ & $\begin{array}{l}\text { Suspended biomass DHA } \\
\text { ( } \mu \mathrm{g} \text { TF per g } g_{\text {biomass }} \text { per day) }\end{array}$ & $\begin{array}{l}\text { Nitrate } \\
\mathrm{RE} \pm \mathrm{SD}(\%)\end{array}$ & $\begin{array}{l}\mathrm{COD} \\
\mathrm{RE} \pm \mathrm{SD}(\%)\end{array}$ & $\begin{array}{l}\text { Phenol } \\
\mathrm{RE} \pm \mathrm{SD}(\%)\end{array}$ & $\begin{array}{l}\text { Phenol loading } \\
\text { rate }\left(\mathrm{g} \mathrm{m}^{-3} \mathrm{~d}^{-1}\right)\end{array}$ & $\begin{array}{l}\text { HRT } \\
\text { (h) }\end{array}$ \\
\hline 13.86 & 9.1 & $95.13 \pm 0.07$ & $93.99 \pm 0.36$ & 100 & 500 & 24 \\
\hline 6.9 & 4.1 & $63.75 \pm 0.57$ & $49.73 \pm 7.62$ & $59.52 \pm 9.6$ & 1000 & 12 \\
\hline
\end{tabular}


After recovery of the bioreactor and re-attaining the steadystate conditions, the salinity of the inlet wastewater increased. For all the examined salinity levels, the increase of salinity led to the reduction of removal efficiencies, but the bioreactor again reached the steady-state and $100 \%$ removal of phenol was achieved by extending the operation days. The results show that phenol degrading bacteria are able to revitalize their metabolic conditions for phenol degradation. The ability of the microorganisms to tolerate the salinity of the wastewater depends on the biomass adaptation to the carbon source. ${ }^{48}$ Since the biomass was fully acclimated to the carbon source, there was not a significant effect on the phenol removal efficiencies. Saline wastewater causes an increase in the membrane permeability of the bacteria leading to the poisoning effect of sodium on cells. ${ }^{49}$ Rotation of the media and the attached biofilm leads to the reduction of the permeability of the cell membrane; consequently, the presence of rotating biofilm in CASIR leads to the reduction of the degree of inhibition of salinity. However, salinity concentrations as high as $20 \mathrm{~g} \mathrm{~L}^{-1}$ contributed to the deterioration of the performance of the CASIR bioreactor, and it was considered the highest salinity level that could be tolerated by phenol degrading organisms. Phenol degradation in saline wastewater by SBR has also been reported by other researchers. ${ }^{\mathbf{1 1 , 1 2 , 5 0}}$ Fig. 6b illustrates the variations in DHA of the attached growth and suspended growth, where the DHA activity of the microbial content of the bioreactor is almost constant up to $15 \mathrm{~g} \mathrm{~L}^{-1}$ of salinity; further increase in salinity to $20 \mathrm{~g} \mathrm{~L}^{-1}$ led to the reduction of DHA. This is much more significant for the suspended biomass, indicating that attached growth biofilm is much more resistant to wastewater salinity.

\subsection{Contribution of attached biofilm to overall performance of CASIR}

Comparing the results of the DHA of suspended biomass and attached growth in the all operating conditions indicated that the DHA of the attached biofilm was higher than that of the suspended biomass. This is due to the higher resistance of the biofilm to the applied shocks. ${ }^{51}$ Higher DHA indicates that the biofilm had a significant impact on the overall performance of the CASIR. Higher activity of the biofilm may be related to the dynamic conditions in the inner layers of biofilm. ${ }^{28}$ In addition, higher local concentration of substrate and enzyme because of the presence of an inert carrier and polysaccharide matrix is the
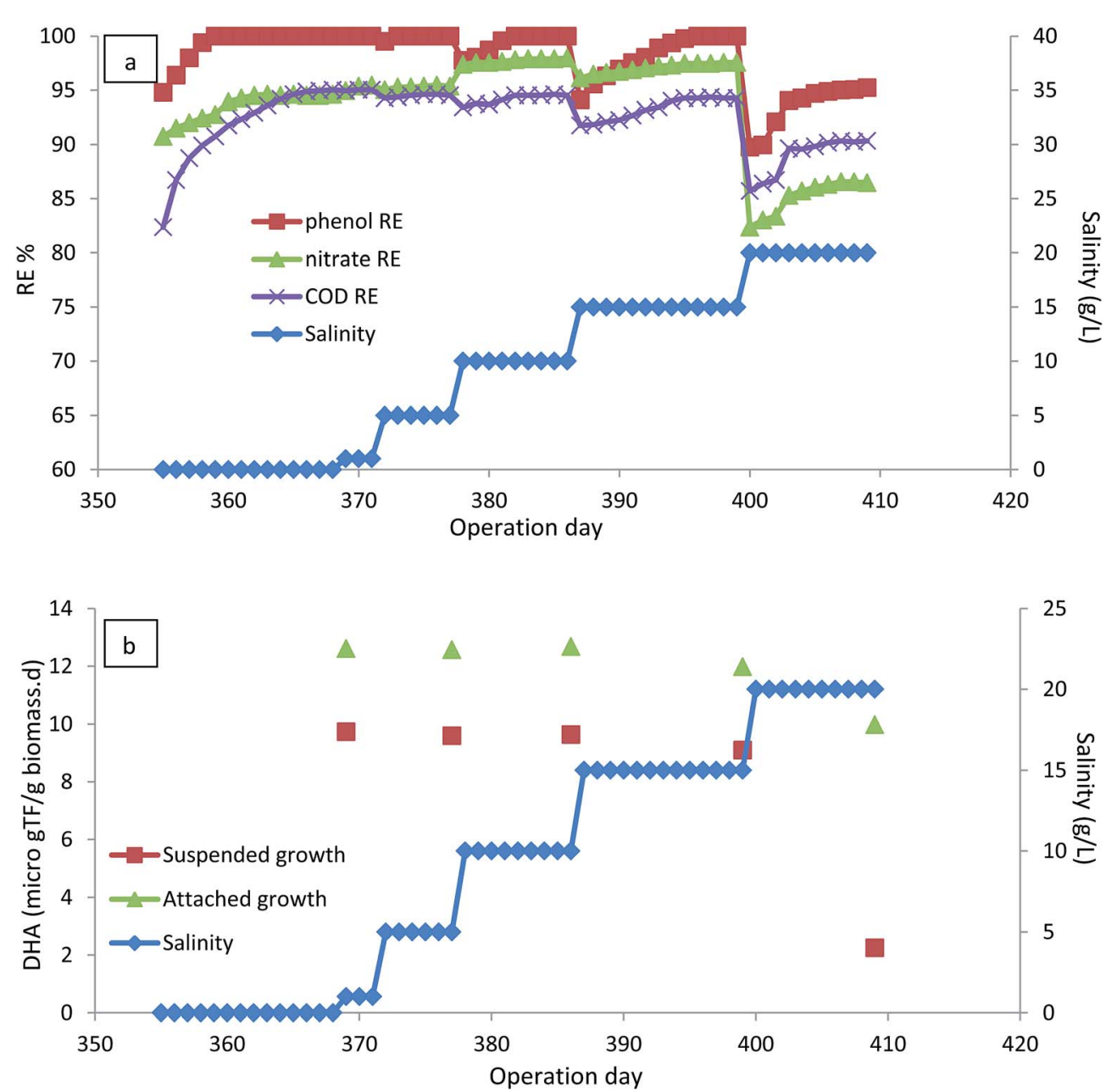

Fig. 6 (a) The effect of salinity on the performance of the CASIR bioreactor. (b) The effect of salinity on the DHA of biomass and biofilm. (HRT = $24 \mathrm{~h}$, inlet phenol concentration $=500 \mathrm{mg} \mathrm{L}^{-1}, \mathrm{MLSS}=4000 \mathrm{mg} \mathrm{L}^{-1}$ ). 
other reason for higher activity of biofilm. ${ }^{28}$ Furthermore, the effect of hydraulic shear and shear stress on the biomass could be the other reason for the higher activity of the biofilm. Rotation of the biofilm in the CASIR bioreactor increases the shear stress and also causes a thin layer of biofilm on the media and therefore, better contact between substrate and microorganism occurs. ${ }^{52}$ Consequently, the integration of rotating media with suspended solid in the CASIR bioreactor improves the overall performance of the bioreactor in the case of phenol removal in denitrifying conditions.

\subsection{The effect of hydrogen peroxide injection}

In order to biostimulate phenol degrading bacteria in the bioreactor, hydrogen peroxide was injected in a controlled flow rate by a syringe pump (Fig. 1). For this purpose, the bioreactor was operated at an inlet phenol concentration of $500 \mathrm{mg} \mathrm{L}^{-1}$, HRT of $12 \mathrm{~h}$, media filing ratio of $40 \%$, and MLSS of $4000 \mathrm{mg} \mathrm{L}^{-1}$. Table 3 shows the average steady-state conditions of bioreactor operation within 73 days. In the first phase, which was operated for 9 days, inlet nitrate concentration was $1190 \mathrm{mg} \mathrm{L}^{-1}$. The injection of hydrogen peroxide caused a slight reduction in the removal efficiencies of phenol and COD concentrations, compared with the conditions when nitrate was the only electron acceptor. Further reduction in removal efficiencies was observed when inlet nitrate concentration was reduced to $900 \mathrm{mg} \mathrm{L}^{-1}$. Under these conditions, the bioreactor deterioration in removal efficiency could be attributed to the toxicity of hydrogen peroxide to the microorganisms and their performance; because of this, toxicity was adversely affected. ${ }^{38}$ In addition, in the initial days of operation, the presence of nitrate in the inlet made the conditions favorable for denitrifying microorganisms to degrade phenol. After achieving the steady-state conditions, the $\mathrm{H}_{2} \mathrm{O}_{2}$ /phenol ratio increased to 0.73 and inlet nitrate concentration was reduced to $600 \mathrm{mg} \mathrm{L}^{-1}$. The bioreactor was operated for 12 days under these conditions. As shown in the table, phenol and COD removal efficiencies became 59.9 and $33.7 \%$, respectively. DHA of the biomass and biofilm also showed a considerable decrease, indicating that the presence of hydrogen peroxide resulted in the deterioration in the performance of the microorganisms. The results show that microbial activity ceased due to the presence of hydrogen peroxide. After reaching the steady-state conditions, the $\mathrm{H}_{2} \mathrm{O}_{2}$ / phenol ratio was increased to 1.10 and nitrate concentration was reduced to $300 \mathrm{mg} \mathrm{L}^{-1}$. Operation of the bioreactor in these conditions led to an increase in phenol and COD removal efficiencies, showing that the microbial biomass was adapting to the presence of hydrogen peroxide. Measuring the DHA at the end of this operational run also showed that the activities of the microorganisms were increasing. PA also increased at the end of this operational run and it was measured to be $49 \mathrm{U} \mathrm{g}_{\text {biomass }}{ }^{-1}$ and $88 \mathrm{U} \mathrm{g}_{\text {biomass }}{ }^{-1}$ for attached growth and suspended growth, respectively. In the next step, inlet nitrate was completely removed and the $\mathrm{H}_{2} \mathrm{O}_{2}$ /phenol ratio was kept constant at 1.10. After 7 days of operation in these conditions, complete degradation of phenol was reached and almost $80 \%$ of the COD was also removed. DHA of the biomass and biofilm was 9.8 and $14.68 \mu \mathrm{g}$ TF per $g_{\text {biomass }}$ per day, respectively. PA of the microorganisms also showed an increasing trend, confirming that the peroxidase enzyme was generated by microorganisms. In addition, the complete degradation of phenol showed that the microbial content of the bioreactor adapted to the presence of hydrogen peroxide and switching of the bioreactor from denitrifying conditions to peroxidase-mediated conditions was completed.

After operation of the bioreactor for almost 50 days, it was observed that MLSS of the system was almost completely removed and all the suspended biomass was attached to the media. In the next experimental runs, the bioreactor was operated only with attached biofilm. This unpredicted change in the bioreactor could be due to the release of hydrophobic exopolymeric substances participating in the increment of cohesiveness of the suspended biomass. ${ }^{53}$ Chao et al. ${ }^{54}$ also reported that higher hydrophobicity was observed in biofilm compared to suspended activated sludge, suggesting that more hydrophobic bacteria existed in biofilms than in suspended activated sludge.

It is important to optimize the amount of injected hydrogen peroxide in the bioreactor for the enzymatic biodegradation of phenol. Therefore, the $\mathrm{H}_{2} \mathrm{O}_{2}$ /phenol ratio was reduced to 0.73 at an inlet phenol concentration of $500 \mathrm{mg} \mathrm{L}^{-1}$. The bioreactor was operated for one week in these conditions. The results show that COD removal efficiency increased to $88.59 \%$. DHA and PA were also showing an increasing trend, indicating that higher $\mathrm{H}_{2} \mathrm{O}_{2}$ concentration was toxic to microbial metabolism and leads in particular to the inactivation of the enzyme. ${ }^{38}$

Table 3 Average steady-state phenol, $\mathrm{COD}$ and nitrate removal efficiencies as a function of $\mathrm{H}_{2} \mathrm{O}_{2} /$ phenol ratio (inlet phenol concentration $=$ $500 \mathrm{mg} \mathrm{L}^{-1}, \mathrm{MLSS}=4000 \mathrm{mg} \mathrm{L}^{-1}, \mathrm{HRT}=12 \mathrm{~h}, \mathrm{OLR}=1000 \mathrm{~g} \mathrm{~m}^{-3} \mathrm{~d}^{-1}$ )

\begin{tabular}{|c|c|c|c|c|c|c|c|c|}
\hline $\begin{array}{l}\text { PA } \\
\text { (attached) }^{b}\end{array}$ & $\begin{array}{l}\text { PA } \\
\text { (suspended) }^{b}\end{array}$ & $\begin{array}{l}\text { DHA } \\
\text { (attached) }^{b}\end{array}$ & $\begin{array}{l}\text { DHA } \\
\text { (suspended) }^{a}\end{array}$ & $\begin{array}{l}\text { Nitrate } \\
\mathrm{RE} \pm \mathrm{SD}(\%)\end{array}$ & $\begin{array}{l}\mathrm{COD} \\
\mathrm{RE} \pm \mathrm{SD}(\%)\end{array}$ & $\begin{array}{l}\text { Phenol } \\
\mathrm{RE} \pm \mathrm{SD}(\%)\end{array}$ & Nitrate in & $\mathrm{H}_{2} \mathrm{O}_{2} /$ phenol \\
\hline 7 & 15 & 6.01 & 2.1 & $50.49 \pm 6.76$ & $47.9 \pm 1.47$ & $58.4 \pm 2.4$ & 1190 & 0.36 \\
\hline 9 & 17 & 3.9 & 0.95 & $98.3 \pm 1.51$ & $33.7 \pm 3.72$ & $59.9 \pm 8.45$ & 600 & 0.73 \\
\hline 88 & 49 & 9.7 & 5.7 & $99.86 \pm 0.48$ & $43.8 \pm 10.74$ & $78.16 \pm 8.5$ & 300 & 1.10 \\
\hline 142 & 94 & 14.68 & 9.8 & - & $75.0 \pm 6.12$ & $98.3 \pm 3.15$ & 0 & 1.10 \\
\hline 289 & - & 17.89 & - & - & $88.18 \pm 0.78$ & 100 & 0 & 0.55 \\
\hline
\end{tabular}




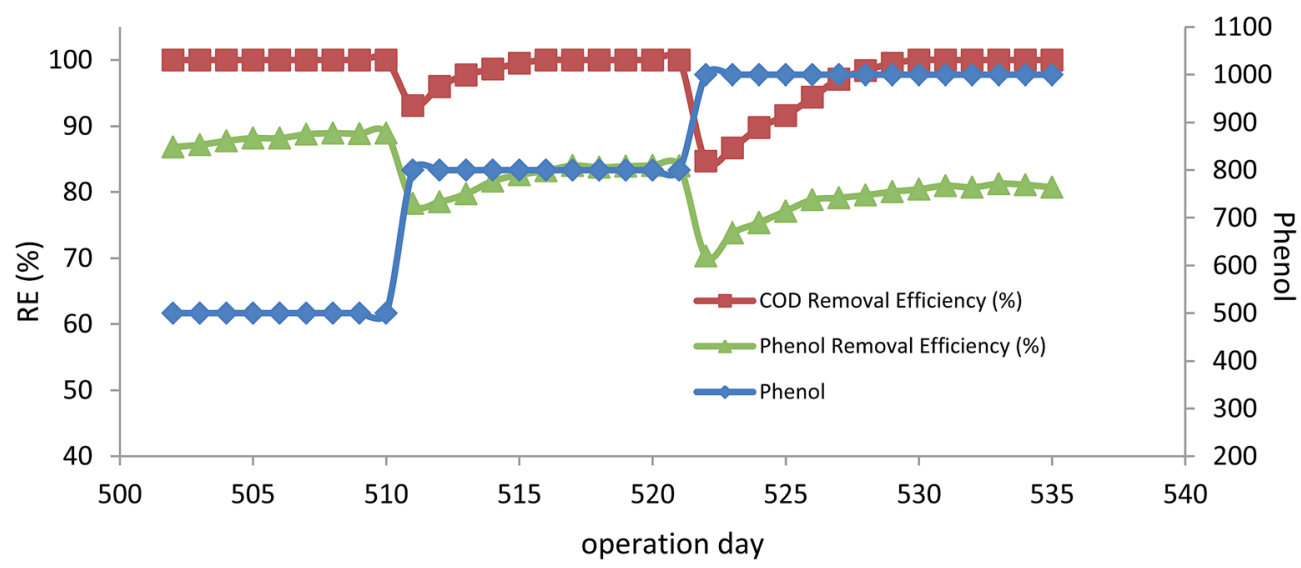

Fig. 7 The effect of inlet phenol concentration in the peroxidase-mediated bioreactor. $\left(H R T=12 h, \mathrm{H}_{2} \mathrm{O}_{2} / \mathrm{phenol}=0.55\right)$.

In the next step, the $\mathrm{H}_{2} \mathrm{O}_{2}$ /phenol ratio was reduced to 0.36. As shown in table, there was a slight reduction in the COD removal efficiency at this ratio, suggesting that injected $\mathrm{H}_{2} \mathrm{O}_{2}$ is not enough for the microbial biostimulation to generate the peroxidase enzyme. Therefore, this ratio was increased to 0.55 and it was observed that the COD removal efficiency increased to almost $88 \%$. DHA and PA were also increased to $17.89 \mu \mathrm{g} \mathrm{TF}$ per $\mathrm{g}_{\text {biomass }}$ per day and $289 \mathrm{U}_{\text {biomass }}{ }^{-1}$, respectively; 0.55 was therefore considered the optimum value for the $\mathrm{H}_{2} \mathrm{O}_{2}$ /phenol ratio.

After optimizing the $\mathrm{H}_{2} \mathrm{O}_{2}$ /phenol ratio, the inlet phenol concentration increased to $800 \mathrm{mg} \mathrm{L}^{-1}$ and $1000 \mathrm{mg} \mathrm{L}^{-1}$ at the optimum $\mathrm{H}_{2} \mathrm{O}_{2} /$ phenol ratio of 0.55 and HRT of 12 h. Fig. 7 illustrates the results of higher inlet phenol concentration in phenol and COD removal, where there was a slight reduction in removal efficiency of phenol after increasing the inlet concentration, but the bioreactor was able to re-attain its performance and the complete degradation of phenol was reached for both 800 and $1000 \mathrm{mg} \mathrm{L}^{-1}$. COD removal efficiency also showed the same trend, and almost $84 \%$ COD removal for $800 \mathrm{mg} \mathrm{L}^{-1}$ of inlet phenol and $80 \%$ for $1000 \mathrm{mg} \mathrm{L}^{-1}$ was reached. Measuring the microbial activity of the biofilm also showed that there was an increase in DHA. At the end of the experimental run for $500 \mathrm{mg} \mathrm{L}^{-1}$ and $1000 \mathrm{mg} \mathrm{L}^{-1}$ of phenol, DHA was 21.58 and $22.25 \mu \mathrm{g}$ TF per g $\mathrm{g}_{\text {biomass }}$ per day, respectively. The increase in the DHA indicates that the microbial activity was increased at higher concentrations and the acclimated biofilm was able to tolerate higher phenol loading rates. The PA of the biofilm remained almost unchanged and was found to be 295 and $290 \mathrm{U}$ $\mathrm{g}_{\text {biomass }}{ }^{-1}$ for 800 and $1000 \mathrm{mg} \mathrm{L}^{-1}$ of the inlet phenol concentration, respectively. Microbial adaptation by $\mathrm{H}_{2} \mathrm{O}_{2}$ for total petroleum hydrocarbon also showed that PA at different experimental runs remained almost constant, ranging from 382-410 U g biomass $^{-1}$. $^{38}$

\subsection{Comparison of the performance of the anoxic and enzymatic degradation of phenol}

Fig. 8 illustrates the performance of anoxic and enzymatic bioreactors at the same phenol loading rate of $1000 \mathrm{~g} \mathrm{~m}^{-3} \mathrm{~d}^{-1}$. The phenol removal efficiency increased from almost $59 \%$ in anoxic conditions to $100 \%$ in enzymatic conditions. COD

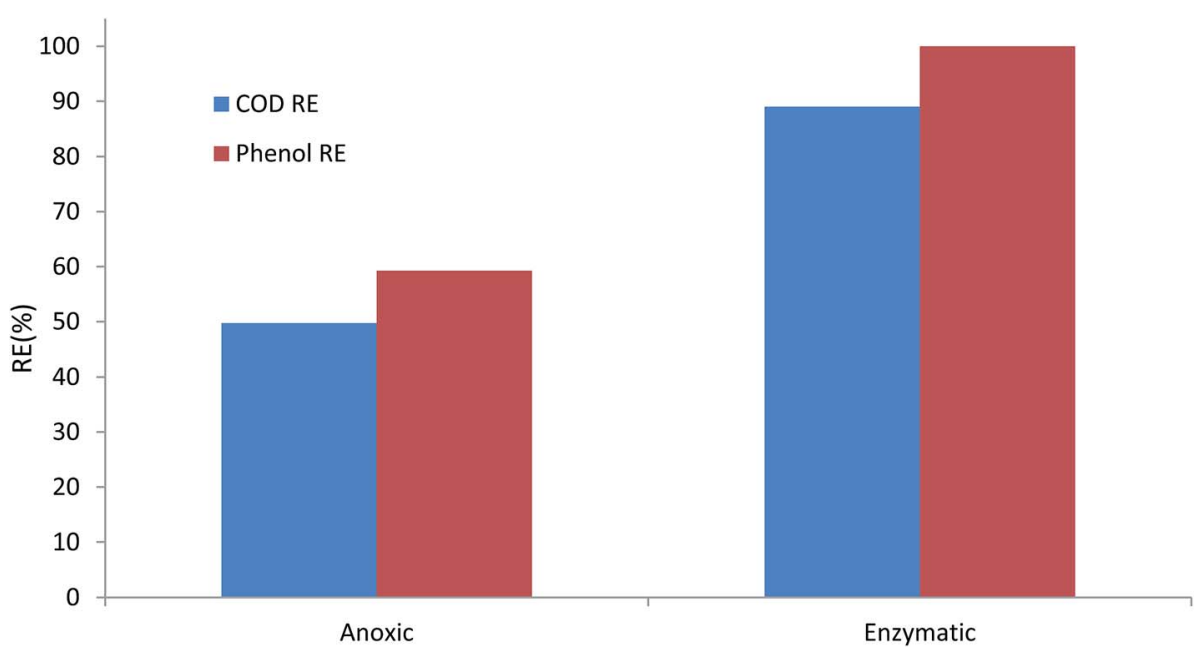

Fig. 8 Comparison of the performance of anoxic and enzymatic degradation of phenol at the same loading rate of $1000 \mathrm{~g} \mathrm{~m}^{-3} \mathrm{~d}^{-1}$. 
removal efficiency also increased considerably. Furthermore, the enzymatic bioreactor was able to tolerate phenol loading rates as high as $2000 \mathrm{~g} \mathrm{~m}^{-3} \mathrm{~d}^{-1}$, and complete degradation of phenol along with almost $81 \%$ COD removal efficiency was reached in the enzymatic process.

Comparing the DHA of the biofilm in anoxic and enzymatic processes also shows that microbial activity in the $\mathrm{H}_{2} \mathrm{O}_{2}$ induced process was also considerably higher, compared to anoxic conditions. The highest DHA for the $\mathrm{H}_{2} \mathrm{O}_{2}$-induced

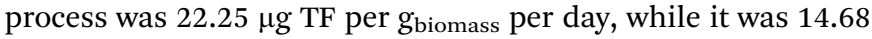
$\mu \mathrm{g}$ TF per $\mathrm{g}_{\text {biomass }}$ per day for anoxic conditions. Higher DHA indicates that the bacterial activity, and thus substrate consumption rate, increased. This could be due to the fact that the injection of $\mathrm{H}_{2} \mathrm{O}_{2}$ at a given concentration stimulated the bacteria, and therefore bacterial growth and biodegradation increased..$^{38}$

Attaining such a high performance of the bioreactor for phenol degradation could be due to the presence of acclimated bacteria capable of phenol degradation. In addition, continuous exposure of the bacteria to low concentrations of hydrogen peroxide stimulated the bacteria to produce peroxidase enzyme and therefore phenol degradation took place. ${ }^{55}$

Comparing the results of peroxidase-mediated phenol degradation with anoxic conditions for phenol degradation revealed that biostimulation of bacteria with the injection of an inconsiderable amount of hydrogen peroxide into the CASIR bioreactor caused the in situ generation of large amounts of peroxidase enzyme, contributing to the degradation of phenol and associated COD.

\section{Conclusion}

The present study describes the performance of the CASIR bioreactor for the degradation of phenol in anoxic conditions and in the presence of hydrogen peroxide. The results reveal that the CASIR bioreactor could completely remove phenol and a large portion of the COD as well as nitrates in anoxic conditions. It was found that greater removal efficiencies were reached with a media filling ratio of $40 \%$. Monitoring the DHA of the biofilm in the bioreactor revealed that the presence of biofilm in the bioreactor made the process more tolerant of applied shocks. It was also found that the CASIR bioreactor was able to completely remove the phenol loading rate of $667 \mathrm{~g} \mathrm{~m}^{-3}$ $\mathrm{d}^{-1}$ in anoxic conditions. The results show that the CASIR bioreactor is able to re-attain its performance after applying an organic loading shock. The salinity of the wastewater was also investigated and it did not affect the performance of the bioreactor. Switching the bioreactor operation from denitrifying conditions to peroxidase-mediated conditions improved the overall performance of the bioreactor. This was done due to the in situ generation of peroxidase enzyme as a result of microbial simulation by hydrogen peroxide. In situ generation of peroxidase enzyme in the bioreactor led to the complete degradation of phenol at the loading rate of $2000 \mathrm{~g} \mathrm{~m}^{-3} \mathrm{~d}^{-1}$. Finally, it can be concluded that using $\mathrm{H}_{2} \mathrm{O}_{2}$-induced microbial cells in a cyclic activated sludge is a promising technique for the enzymatic degradation of phenol and corresponding COD.

\section{Conflicts of interest}

There are no conflicts to declare.

\section{Acknowledgements}

The authors are grateful to the Tarbiat Modares University for providing technical and instrumental support. This study was financially supported by grant No: 950403 of the Biotechnology Development Council of the Islamic Republic of Iran.

\section{Notes and references}

1 T. Senthilvelan, J. Kanagaraj, R. C. Panda and A. B. Mandal, Clean Technol. Environ. Policy, 2014, vol. 16, pp. 113-126.

2 E. Kaczorek, W. Smułek, A. Zdarta, A. Sawczuk and A. ZgołaGrześkowiak, Ecotoxicol. Environ. Saf., 2016, 131, 127-134.

3 EPA, Update of Human Health Ambient Water Quality Criteria: 2,4-Dimethylphenol 105-67-9, Office of Science and Technology Office of Water, EPA 820-R-15-085, 2015.

4 M. Li, D. Wen, Z. Qiang and J. Kiwi, RSC Adv., 2017, 7, 76407647.

5 T. Zhang, L. Cheng, L. Ma, F. Meng, R. G. Arnold and A. E. Sáez, Chemosphere, 2016, 161, 349-357.

6 L. Yang, B. Wang, S. Lai, C. Jiang and H. Zhong, RSC Adv., 2015, 5, 53299-53305.

7 L. Mekuto, S. K. O. Ntwampe and A. Akcil, Sci. Total Environ., 2016, 571, 711-720.

8 M. Garfí, L. Flores and I. Ferrer, J. Cleaner Prod., 2017, 161, 211-219.

9 Y. Wu, Q. Sun, Y.-w. Wang, C.-x. Deng and C.-P. Yu, Ecotoxicol. Environ. Saf., 2017, 138, 25-31.

10 Y. Chen, J. He, Y.-Q. Wang, T. A. Kotsopoulos, P. Kaparaju and R. J. Zeng, Biochem. Eng. J., 2016, 106, 19-25.

11 E. Ferrer-Polonio, N. T. García-Quijano, J. A. Mendoza-Roca, A. Iborra-Clar and L. Pastor-Alcañiz, Biochem. Eng. J., 2016, 113, 57-65.

12 E. Ferrer-Polonio, J. A. Mendoza-Roca, A. Iborra-Clar, J. L. Alonso-Molina and L. Pastor-Alcañiz, J. Ind. Eng. Chem., 2016, 43, 44-52.

13 Q. Liu, V. P. Singh, Z. Fu, J. Wang and L. Hu, Environ. Sci. Pollut. Res. Int., 2017, 24, 11789-11799.

14 C. P. L. Grady, G. T. Daigger, N. G. Love and C. D. M. Filipe, Biological Wastewater Treatment, Third Edition, CRC Press, 2011.

15 A. F. Ramos, M. A. Gomez, E. Hontoria and J. GonzalezLopez, J. Hazard. Mater., 2007, 142, 175-183.

16 L.-F. Ren, R. Chen, X. Zhang, J. Shao and Y. He, Bioresour. Technol., 2017, 244, 1121-1128.

17 M. H. Muhamad, S. R. Sheikh Abdullah, H. Abu Hasan and R. A. Abd Rahim, J. Environ. Manage., 2015, 163, 115-124.

18 A. S. Oberoi and L. Philip, J. Environ. Chem. Eng., 2017, 5, 3852-3864.

19 G. Tziotzios, M. Teliou, V. Kaltsouni, G. Lyberatos and D. V. Vayenas, Biochem. Eng. J., 2005, 26, 65-71.

20 N. Yusoff, S.-A. Ong, L.-N. Ho, Y.-S. Wong, F. N. Mohd Saad, W. Khalik and S.-L. Lee, Biochem. Eng. J., 2016, 115, 14-22. 
21 J. C. Leyva-Díaz, K. Calderón, F. A. Rodríguez, J. GonzálezLópez, E. Hontoria and J. M. Poyatos, Biochem. Eng. J., 2013, 77, 28-40.

22 M. B. Asif, L. N. Nguyen, F. I. Hai, W. E. Price and L. D. Nghiem, Int. Biodeterior. Biodegrad., 2017, 124, 73-81.

23 A. H. Alneyadi and S. S. Ashraf, Chem. Eng. J., 2016, 303, 529538.

24 M. Zappi, K. White, H. M. Hwang, R. Bajpai and M. Qasim, J. Air Waste Manag. Assoc., 2000, 50, 1818-1830.

25 S. J. Jafari, G. Moussavi and K. Yaghmaeian, Bioresour. Technol., 2015, 197, 482-488.

26 G. Moussavi, S. J. Jafari and K. Yaghmaeian, Bioresour. Technol., 2015, 189, 266-272.

27 L. S. Clesceri, A. E. Greenberg and A. D. Eaton, Standard Methods for the Examination of Water and Wastewater, 20th Edition, APHA American Public Health Association, 1998.

28 I. Schneider and Y. Topalova, Biotechnol Biotechnol Equip., 2013, 27, 3782-3786.

29 J. Xie, W. Hu, H. Pei, M. Dun and F. Qi, Environ. Monit. Assess., 2008, 146, 473-478.

30 N. Tandjaoui, A. Tassist, M. Abouseoud, A. Couvert and A. Amrane, Biocatal. Agric. Biotechnol., 2015, 4, 208-213.

31 M. H. El-Naas, S. Al-Zuhair and S. Makhlouf, Chem. Eng. J., 2010, 160, 565-570.

32 S. Sarfaraz, S. Thomas, U. K. Tewari and L. Iyengar, Water Res., 2004, 38, 965-971.

33 M. Bajaj, C. Gallert and J. Winter, Bioresour. Technol., 2010, 101, 5159-5167.

34 F. Rosenkranz, L. Cabrol, M. Carballa, A. Donoso-Bravo, L. Cruz, G. Ruiz-Filippi, R. Chamy and J. M. Lema, Water Res., 2013, 47, 6739-6749.

35 T. Chen, X. Liu, X. Zhang, X. Chen, K. Tao and X. Hu, Chemosphere, 2016, 154, 515-520.

36 I.-G. Byun, H.-U. Nam, S. K. Song, I.-S. Hwang, T.-H. Lee and T.-J. Park, Korean J. Chem. Eng., 2005, 22, 917-921.

37 G. Moussavi and M. Ghorbanian, Chem. Eng. J., 2015, 280, 121-131.
38 G. Moussavi, S. Shekoohiyan and K. Naddafi, Chem. Eng. J., 2017, 308, 1081-1089.

39 A. Damayanti, Z. Ujang, M. R. Salim and G. Olsson, Water Sci. Technol., 2011, 63, 1701-1706.

40 A.-j. Li, X.-y. Li and H.-q. Yu, Process Biochem., 2011, 46, 2269-2276.

41 E. Marañón, I. Vázquez, J. Rodríguez, L. Castrillón, Y. Fernández and H. López, Bioresour. Technol., 2008, 99, 4192-4198.

42 A. Uygur and F. Kargi, Process Biochem., 2004, 39, 2123-2128.

43 G. Moussavi, M. Mahmoudi and B. Barikbin, Water Res., 2009, 43, 1295-1302.

44 R.-S. Juang, H.-C. Kao and K.-J. Tseng, Sep. Purif. Technol., 2010, 71, 285-292.

45 E. Acikgoz and B. Ozcan, Int. Biodeterior. Biodegrad., 2016, 107, 140-146.

46 R. D. Tyagi, Y. G. Du and R. Bhamidimarri, Water Res., 1996, 30, 1605-1616.

47 L. Li, S. Suwanate and C. Visvanathan, Bioresour. Technol., 2017, 240, 3-8.

48 J. P. Bassin, R. Kleerebezem, G. Muyzer, A. S. Rosado, M. C. van Loosdrecht and M. Dezotti, Appl. Microbiol. Biotechnol., 2012, 93, 1281-1294.

49 W. Zhao, Y. Wang, S. Liu, M. Pan, J. Yang and S. Chen, Chem. Eng. J., 2013, 215, 252-260.

50 G. Moussavi, B. Barikbin and M. Mahmoudi, Chem. Eng. J., 2010, 158, 498-504.

51 G. T. Daigger, Upgrading Wastewater Treatment Plants, Second Edition, Taylor \& Francis, 1998.

52 Y. Liu and J. H. Tay, J. Appl. Microbiol., 2001, 90, 337-342.

53 F. Jorand, F. Boué-Bigne, J. C. Block and V. Urbain, Water Sci. Technol., 1998, 37, 307-315.

54 Y. Chao, F. Guo, H. H. P. Fang and T. Zhang, Colloids Surf., B, 2014, 114, 379-385.

55 D. H. Y. Yanto and S. Tachibana, Chemosphere, 2014, 103, 105-113. 